\title{
The Role of Soil Characteristics on Temperature Sensitivity of Soil Organic Matter
}

\section{Michelle L. Haddix*}

Natural Resource Ecology Laboratory

200 West Lake Street

Colorado State University

Fort Collins, CO 80523-1499

\section{Alain F. Plante}

Dep. of Earth \& Environmental Science

240 South 33rd Street

University of Pennsylvania,

Philadelphia, PA 19104-6316

\section{Richard T. Conant}

Natural Resource Ecology Laboratory

200 West Lake Street

Colorado State University

Fort Collins, CO 80523-1499

\section{Johan Six}

Dep. of Plant Sciences

University of California

One Shields Avenue

Davis, CA 95616

\section{J. Megan Steinweg}

Natural Resource Ecology Laboratory Graduate Degree Program in Ecology 200 West Lake Street

Colorado State University

Fort Collins, CO 80523-1499

\section{Kim Magrini-Bair}

National Renewable Energy Laboratory 1617 Cole Blvd.

Golden, CO 80401

\section{Rhae A. Drijber}

Dep. of Agronomy and Horticulture 377P Plant Science

University of Nebraska

Lincoln, NE 68583-0915

\section{Sherri J. Morris}

Biology Department

Bradley University

1501 W. Bradley Ave.

Peoria, IL 61625

\section{Eldor A. Paul}

Natural Resource Ecology Laboratory Dep. of Soil and Crop Sciences

200 West Lake Street

Colorado State University

Fort Collins, CO 80523-1499
The uncertainty associated with how projected climate change will affect global $\mathrm{C}$ cycling could have a large impact on predictions of soil $\mathrm{C}$ stocks. The purpose of our study was to determine how various soil decomposition and chemistry characteristics relate to soil organic matter (SOM) temperature sensitivity. We accomplished this objective using long-term soil incubations at three temperatures $\left(15,25\right.$, and $\left.35^{\circ} \mathrm{C}\right)$ and pyrolysis molecular beam mass spectrometry (py-MBMS) on 12 soils from 6 sites along a mean annual temperature (MAT) gradient $\left(2-25.6^{\circ} \mathrm{C}\right)$. The $\mathrm{Q}_{10}$ values calculated from the $\mathrm{CO}_{2}$ respired during a long-term incubation using the $\mathrm{Q}_{10-\mathrm{q}}$ method showed decomposition of the more resistant fraction to be more temperature sensitive with a $Q_{10-q}$ of $1.95 \pm 0.08$ for the labile fraction and a $Q_{10 \text {-q }}$ of $3.33 \pm 0.04$ for the more resistant fraction. We compared the fit of soil respiration data using a two-pool model (active and slow) with first-order kinetics with a three-pool model and found that the two and three-pool models statistically fit the data equally well. The three-pool model changed the size and rate constant for the more resistant pool. The size of the active pool in these soils, calculated using the two-pool model, increased with incubation temperature and ranged from 0.1 to $14.0 \%$ of initial soil organic $\mathrm{C}$. Sites with an intermediate MAT and lowest $\mathrm{C} / \mathrm{N}$ ratio had the largest active pool. Pyrolysis molecular beam mass spectrometry showed declines in carbohydrates with conversion from grassland to wheat cultivation and a greater amount of protected carbohydrates in allophanic soils which may have lead to differences found between the total amount of $\mathrm{CO}_{2}$ respired, the size of the active pool, and the $\mathrm{Q}_{10-\mathrm{q}}$ values of the soils.

Abbreviations: MAT, mean annual temperature; PCA, principle component analysis; PLS, partial least square; py-MBMS, pyrolysis molecular beam mass spectrometry; SOC, soil organic C; SOM, soil organic matter.

$\mathrm{T}$ emperature is an important factor controlling SOM turnover and understanding how temperature affects SOM decomposition will allow us to better predict how global climate change will affect SOM stocks. Understanding the temperature sensitivity of SOM decomposition is challenging because SOM is composed of many different organic $\mathrm{C}$ compounds, with differing inherent kinetic properties (Davidson and Janssens, 2006). To simplify the process of modeling SOM decomposition, this range of compounds is usually classified into a small number of discrete, kinetically defined pools with some portion of SOM being easily decomposable and the rest comprising one or more other pools decomposing more slowly.

In most decomposition models, temperature effects are modeled as a decomposition rate multiplier for fixed SOM pools (Lloyd and Taylor, 1994; Del Grosso et al., 2005), but some recent studies have hypothesized that temperature may actually alter the amount of substrate that would be considered easily decomposable (Zogg et al., 1997; Zak et al., 1999; Dalias et al., 2003; Rasmussen et al., 2006). The most broadly used terrestrial C models typically have a fixed $\mathrm{Q}_{10}$ of 1.5 to 2.0 or an Arrhenius-type function with the same respiration-temperature relationship to each of the different SOM pools (Melillo et al., 1995; Burke et al., 2003; Friedlingstein et al., 2006). Many recent studies have found that different SOM pools have different temperature responses, although consensus on their apparent

Soil Sci. Soc. Am. J. 75:56-68

Posted online 30 Nov. 2010

doi:10.2136/sssaj2010.0118

Received 12 Mar. 2010.

*Corresponding author (mlhaddix@nrel.colostate.edu).

(C) Soil Science Society of America, 5585 Guilford Rd., Madison WI 53711 USA

All rights reserved. No part of this periodical may be reproduced or transmitted in any form or by any means, electronic or mechanical, including photocopying, recording, or any information storage and retrieval system, without permission in writing from the publisher. Permission for printing and for reprinting the material contained herein has been obtained by the publisher. 


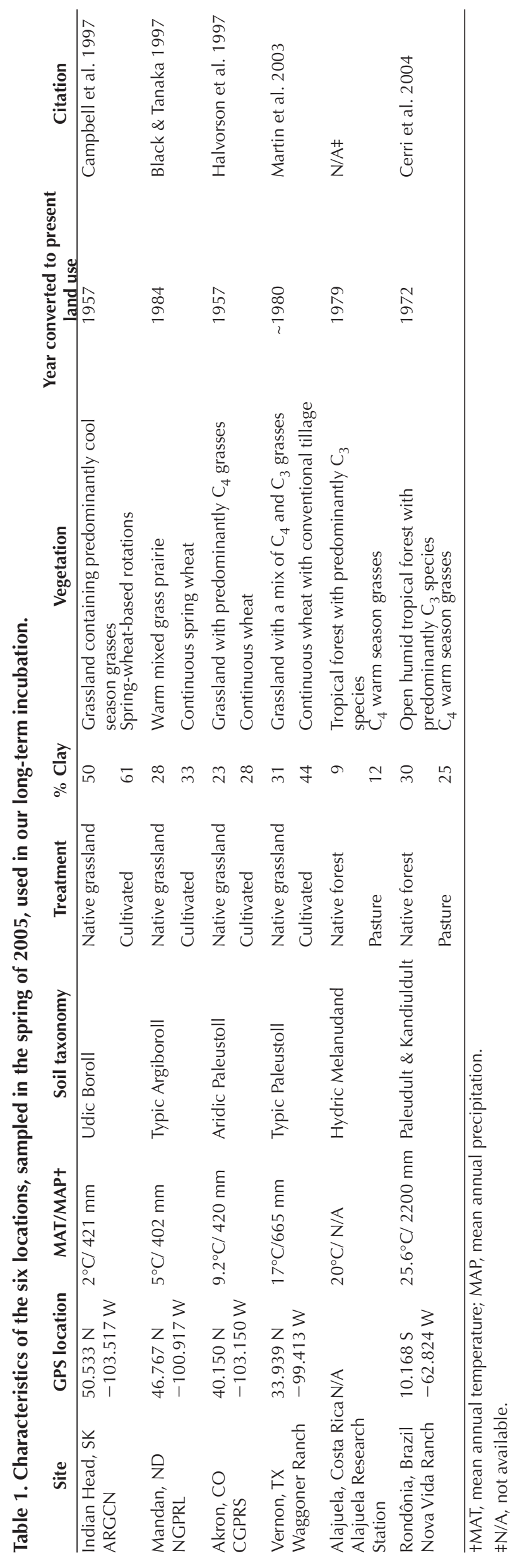

temperature sensitivities has not yet been reached (Davidson and Janssens, 2006). Some have found that the more labile SOM is more temperature sensitive (Liski et al., 1999; Giardina and Ryan, 2000), while others have found that the less labile SOM is more temperature sensitive (Bosatta and Ågren, 1999; Bol et al., 2003; Knorr et al., 2005; Fierer et al., 2005). Still other studies have found results indicating different SOM fractions have the same temperature sensitivity (Fang et al., 2005; Conen et al., 2006).

Not only can temperature have variable effects on the organic matter within a soil, but also between soils with different MAT. Fang et al. (2005) predicted the greatest loss of SOM will be in soils where the present MAT $<4^{\circ} \mathrm{C}$ and that SOM loss will decrease with increasing MAT. Trumbore et al. (1996) predicted that a $0.5^{\circ} \mathrm{C}$ rise in temperature could cause a release of approximately 1.4 Pg of $\mathrm{C}$ from forest soils, with much of this response occurring in the tropics. Temperature may also have varying effects on the soil depending on the type of organic matter in the soil. Soils under long-term cultivation would likely have less labile $\mathrm{C}$ compared with native soils with minimal disturbance.

Apparent temperature responses can vary substantially when different methods are used to assess temperature sensitivity and similar methods have found varying results between different soils (e.g., Conen et al., 2006 and Vanhala et al., 2007). Even after accounting for other factors ameliorating temperature controls on decomposition, such as substrate availability, soil moisture, and soil texture, there is significant variation in decomposition responses to differences in temperature (e.g., Fissore et al., 2009; Gillabel et al., 2010). These inconsistencies make it difficult to make any broad generalizations about the temperature sensitivity of SOM with varying quality.

The objective of this study was to explain differences in the temperature sensitivities of SOM decomposition between different soils. We hypothesize that the more resistant SOM is more temperature sensitive than labile SOM because it is comprised of more complex molecules that have slower decomposition rates and presumed higher activation energies. Higher activation energy has been demonstrated to be related to greater temperature sensitivity (Bosatta and Ågren 1999; Mikan et al., 2002). We expanded on previous incubation studies, both in terms of incubation duration and number of soils examined-and employed curve fitting and molecular beam mass spectrometry to characterize the SOM in the soils. Soils from paired sites with different long-term land uses along a MAT gradient were used to compare similar soils with differing amounts and types of SOM. By utilizing this multi-approach method we sought a better understanding of the apparent temperature sensitivity of SOM.

\section{MATERIALS AND METHODS Sample Sites}

Surface soil samples were collected from six sites along a MAT gradient $\left(2-25.6^{\circ} \mathrm{C}\right)$. Each of the temperate sites had a native grassland and cultivated land use (Indian Head, SK; Mandan, ND; Akron, $\mathrm{CO}$; and Waggoner Ranch, TX) and the tropical sites had a native forest and pasture land use (Alajuela, Costa Rica, and Nova Vida 
Ranch, Brazil; Table 1). Samples were collected from three locations separated by several meters each (field replicate $n=3$ ) within each land use. Surface litter and aboveground vegetation were cleared away before sampling. Small pits were dug to a depth of $20 \mathrm{~cm}$, and samples were collected from 0 to $20 \mathrm{~cm}$. Soils were packaged and transported to the laboratory, where rocks, surface litter, and root materials were removed. Our soil incubation is an analytical technique, not used to understand rates of respiration in the field. To maximize the likelihood of observed meaningful respiration, the soil was homogenized by gently breaking large soil clods by hand and passing the soil through a 2-mm sieve. Soil samples were air-dried and stored at room temperature until incubations began. Soil organic $\mathrm{C}$ (SOC) and total $\mathrm{N}$ concentrations were determined with a LECO CHN-1000 autoanalyzer (LECO Corp., St. Joseph, MI).

\section{Laboratory Incubation}

Four laboratory replicates from composite field samples from each site and treatment combination were incubated at 15, 25, and $35^{\circ} \mathrm{C}$ for $588 \mathrm{~d}$. For each sample, $80 \mathrm{~g}$ of soil were wetted up to $60 \%$ water filled pore space to optimize microbial activity (Linn and Doran, 1984). Gravimetric soil moisture was periodically checked throughout the incubation and water was added when water loss was $>5 \%$ of initial water added. Samples were placed in sealed canning jars fitted with septa, along with scintillation vials containing $20 \mathrm{~mL}$ of water to maintain humidity. Incubation starting days were staggered by replicate and each replicate of a soil was measured on a different day to take into account daily measurement variability. Soils were pre-incubated for $3 \mathrm{~d}$ at $25^{\circ} \mathrm{C}$ and then $4 \mathrm{~d}$ at the respective incubation temperature before measurements to allow the soil to equilibrate after wetting up (Paul et al., 2001). Headspace gas samples were analyzed for $\mathrm{CO}_{2}$ concentration using a Li-Cor LI-6252 infra red gas analyzer (IRGA) (LI-COR Biosciences, Lincoln, NE). Jars were flushed with compressed tank air before $\mathrm{CO}_{2}$ concentrations reached $5 \%(\mathrm{v} / \mathrm{v})$ to prevent $\mathrm{CO}_{2}$ concentration from inhibiting microbial activity. Through the majority of the incubation periods $\mathrm{CO}_{2}$ concentrations were well below the $5 \%$ level and $\mathrm{O}_{2}$ concentrations were well above $10 \%(\mathrm{v} / \mathrm{v})$, which is thought to be the point where microbial activity may be limited (Kandeler, 2007). The $\mathrm{CO}_{2}$ measurements were taken daily during the first 2 wk of the incubation, weekly for the next $2 \mathrm{wk}$, and then every 4 wk thereafter, generating a total of 36 sampling times over the course of $588 \mathrm{~d}$. Statistical comparisons of cumulative respiration were done by treating the six different sites as random variable replicates (PROC MIXED, SAS Institute, Cary NC).

\section{Temperature Sensitivity}

We wanted to compare the temperature sensitivity of labile and more resistant SOM from our soil incubation to test our hypothesis that the more resistant SOM is more temperature sensitive than labile SOM because it is comprised of more complex molecules that have slower decomposition rates and higher activation energies. Temperature sensitivity of SOM decomposition was determined using the $\mathrm{Q}_{10-\mathrm{q}}$ method described by Conant et al. (2008a) utilizing the $\mathrm{CO}_{2}$ respired from our long-term incubations. The method involves determining the amount of time needed for a given amount of $\mathrm{C}$ to be respired at a given temperature. The time required to respire a fixed amount of $\mathrm{C}$ at two temperatures is then used to calculate a $\mathrm{Q}_{10}$ value. There are two assumptions associated with this method (Conant et al., 2008a). The first is that changes in decomposition rates during the incubation are due to changes in available and easily decomposable substrate. The second is that the effect temperature has on the sequence in which SOM compounds are decomposed is small relative to the effect of temperature on decomposition rates. While soil microbial biomass has been found to decline over time in long-term incubations (Follett et al., 2007), this decline in biomass has not been found to limit the microorganism's capacity to decompose organic matter in long-term incubations (Follett et al., 2007; Steinweg et al., 2008). Because of this we believe that our first assumption that changes in decomposition rates are due to changes in easily decomposable substrate is reasonable.

The $\mathrm{Q}_{10-\mathrm{q}}$ values for the more labile portion of the SOM were determined by dividing the time taken to respire the initial $0.5 \%(\mathrm{w} / \mathrm{w})$ of soil $\mathrm{C}$ at $25^{\circ} \mathrm{C}$ by the time taken at $35^{\circ} \mathrm{C}$. For the more resistant portion, the time taken to respire the last $0.5 \%$ of soil $\mathrm{C}$ respired at $25^{\circ} \mathrm{C}$ temperature (e.g., Colorado Native $12.5-13.0 \%$ soil $\mathrm{C}$ respired) was divided by the time taken to respire the same portion of soil $\mathrm{C}$ at $35^{\circ} \mathrm{C}$. We were interested in examining the responses of rates of decomposition of a fixed amount of soil C. The first $0.5 \%$ and last $0.5 \%$ of SOM respired are operational definitions of labile SOM and more resistant SOM and are subsequently referred to as the labile and more resistant fraction. Since incubation starting days were staggered by replicate and each replicate of a soil was measured on a different day, the time it took to respire a given amount of soil $\mathrm{C}$ for the two temperatures was paired by replicate. The $15^{\circ} \mathrm{C}$ respiration data were not used due to the limited amount of $\mathrm{C}$ respired by the Costa Rica pasture soil. Statistical comparisons of $\mathrm{Q}_{10-\mathrm{q}}$ values were done by treating the six different sites as random variable replicates (PROC MIXED, SAS Institute, Cary NC). Comparisons between $\mathrm{Q}_{10-\mathrm{q}}$ values and the other soil characteristics were performed with the average from each soil.

\section{Curve Fitting}

We used $\mathrm{CO}_{2}$ respiration results from the 15,25 , and $35^{\circ} \mathrm{C}$ incubations for curve fitting. Curve fitting was utilized as a method to describe the size and kinetics of the SOM as one means of characterizing the SOM at our sites. The respiration results from the four laboratory replicates of each site-treatment-temperature combination were averaged, and mean respiration rates were used to determine pool size and decomposition rate constants by curve fitting. Pool size and decomposition rate constants were determined using a two-pool model where the two pools, active $\left(\mathrm{C}_{\mathrm{a}}\right)$ and slow pools $\left(\mathrm{C}_{\mathrm{s}}\right)$, sum to the total soil C $\left(\mathrm{C}_{\text {soil }}\right)$ :

$C_{\text {soil }}=C_{a}+C_{S}$

We used a two-pool first-order equation (Andren and Paustian, 1987):

$$
C_{\text {cum }}(t)=C_{a}\left(1-e^{-k_{a}{ }^{*} t}\right)+C_{s}\left(1-e^{-k_{s}{ }^{*} t}\right)
$$

where $\mathrm{C}_{\text {cum }}(t)$ is the cumulative soil respiration at time $t\left(\mu \mathrm{g} \mathrm{C} \mathrm{g}{ }^{-1}\right.$ soil), $\mathrm{C}_{\mathrm{a}}$ is the size of the active fraction ( $\mu \mathrm{g} \mathrm{C} \mathrm{g}{ }^{-1}$ soil), and $\mathrm{C}_{\mathrm{s}}$ is the 
size of the slow fraction ( $\mu \mathrm{g} \mathrm{C} \mathrm{g}^{-1}$ soil). The parameters $k_{\mathrm{a}}$ and $k_{\mathrm{s}}$ are the decomposition rate constants $\left(\mathrm{d}^{-1}\right)$ for the active and slow pools, respectively. We used data from rate curves rather than cumulative respiration because this minimized error accumulation through time (Hess and Schmidt, 1995). We used the following rate form of Eq. [2] from Paul et al. (2001) to determine parameter estimates:

$$
\frac{\Delta C_{c u m}}{\Delta t}=C_{a}{ }^{*} k_{a}\left(e^{-k_{a}{ }^{*} t}\right)+C_{s}{ }^{*} k_{s}\left(e^{-k_{s}{ }^{*} t}\right)
$$

where $\Delta C_{\text {cum }} / \Delta t$ is in units of $\mu \mathrm{g} \mathrm{C}^{-1}$ soil $\mathrm{d}^{-1}$. The size of the active and slow pools adds up to the total amount of $\mathrm{C}$ in the soil $\left(C_{\text {soil }}\right)(\mathrm{Eq}$. [1]); causing $C_{s}$ to be determined by the difference of the total soil C and the active pool $\mathrm{C}$. This method of curve fitting also implies that changes in respiration rate over the course of an incubation are due to changes in SOM lability.

A three-pool model with first-order kinetics has been found to effectively describe SOC dynamics (Paustian et al., 1992); because of this result we also fit our respiration rate curves to a three-pool first-order equation. We used the same rate equation as the two-pool model (Eq. [3]) and included a resistant pool that was estimated to be $50 \%$ of the total soil C. The decomposition rate for the resistant pool was estimated using a field mean residence time of $500 \mathrm{yr}$ and $\mathrm{Q}_{10}$ adjustment of 2 for the different incubation temperatures. This calculation was only done for comparative purposes. Parameter estimates and subsequent temperature sensitivity calculations were derived from the two-pool equation.

Best fit parameters $\left(C_{\mathrm{a}}, k_{\mathrm{a}}\right.$, and $\left.\mathrm{k}_{\mathrm{s}}\right)$ for the two-pool model were estimated using nonlinear regression of the $\mathrm{CO}_{2}$ evolved with time in SAS v9.2 PROC NLIN with the Gauss method (SAS Institute, Cary $\mathrm{NC}$ ). The only restriction imposed on parameters is that the values had to be greater than zero. There were three instances (North Dakota native grassland $15^{\circ} \mathrm{C}$, Colorado native grassland $15^{\circ} \mathrm{C}$, and Colorado cultivated $15^{\circ} \mathrm{C}$ ) where slow pool decomposition rates were not positive and these three soils were not used in subsequent analyses. The errors associated with model parameters are standard error of the model determined in SAS NLIN. Statistical comparisons of active pool size were done by treating the six different sites as random variable replicates (PROC MIXED, SAS Institute, Cary NC).

\section{Pyrolysis-Molecular Beam Mass Spectrometry}

Chemical composition of SOM was characterized using pyMBMS (Magrini et al., 2002; Hoover et al., 2002). Two subsamples $(\sim 0.1 \mathrm{~g})$ from each field replicate sample were weighed in quartz boats and pyrolyzed in a reactor consisting of a quartz tube $(2.5-\mathrm{cm}$ i.d.) with He flowing through at $5 \mathrm{~L} \mathrm{~min}^{-1}$ heated and maintained at $500^{\circ} \mathrm{C}$. The molecular beam system consisted of an ExtrelTM Model TQMS C50 mass spectrometer for both pyrolysis and combustion vapor analysis. Mass spectral data from $\mathrm{m} / \mathrm{z} 20$ to 500 were acquired on a Teknivent Vector 2TM data acquisition system using $22 \mathrm{eV}$ electron impact ionization and programmed storage in a personal computer. Repetitive scans (typically one $480 \mathrm{amu}$ scan $\mathrm{s}^{-1}$ ) were recorded during the evolution of a pyrolysis wave from each soil sample.

Overall, 36 samples were collected from the field (6 sites $\times 3$ field replicates $\times 2$ land uses). Two aliquots from each of these 36 were analyzed by py-MBMS, resulting in 72 total spectra. Two spectra from the analyses of samples from Saskatchewan and one from North Dakota were excluded from further analysis due to data quality issues (reduced signal), leaving a total of 69 spectra.

Signal intensities from individual spectra $(\mathrm{m} / \mathrm{z} 20-500)$ were standardized to $100 \%$ total ion intensity (TII, the sum of the intensity for each $\mathrm{m} / \mathrm{z}$ ), and reduced data sets ( $\mathrm{m} / \mathrm{z} 57-500)$ were used in the multivariate analyses to omit the small mass units typical of water, $\mathrm{CO}_{2}$, and other volatiles. We used principal component analysis (PCA) to group samples by similarity with samples having similar chemical compositions being tightly grouped in a PCA score plot, while samples with dissimilar and heterogeneous compositions were more scattered (Schulten et al., 1988). Eight principal components and full cross validation were used to build the PCA model to determine whether SOM composition could be grouped by site or land use. Partial least squares (PLS) regression analysis was used to predict the dependent variables (i.e., the model estimates for respiration rates during incubation at 15,25 , and $35^{\circ} \mathrm{C}$ ) from our set of independent variables (i.e., the signal intensities from the py-MBMS spectra). Two PLS regressions were performed: one for the respiration rates early in the incubation when the respiration is mostly from the active pool (Day 5 of the incubation), and one for respiration rates later in the incubation when the respiration is mostly from the slow pool (Day 225 of the incubation). Full cross-validation and Martens' uncertainty test were used to determine statistically significant correlations between pyMBMS spectral data and the biological properties of the samples. Partial least squares analyses were performed iteratively to determine which independent variables were significant based on Martens' uncertainty test, and then subsequent PLS analyses were performed using only the significant variables. This process was repeated until all independent variables were found to be significant. All multivariate analyses were performed using the Unscrambler v.8.0 software package (CAMO Process AS, Oslo, Norway).

\section{RESULTS}

\section{Site Comparisons}

Soil organic C (SOC) concentrations $(0-20 \mathrm{~cm})$ ranged from 6.9 to $200 \mathrm{~g} \mathrm{~kg}^{-1}$ among the six sites (Table 2). The Costa Rican soil is allophanic and consequently had much higher SOC concentrations than the other five sites. Soil organic $\mathrm{C}$ and total $\mathrm{N}$ concentrations differed between land use within each site (except for Texas), with SOC and total N concentrations decreasing after land-use conversion at Saskatchewan, North Dakota, Colorado, and Costa Rica.

Due to the large differences in SOC content among soils, the total amount of $\mathrm{C}$ respired was standardized for the initial amount of SOC. When sites were treated as replicates and the amount of cumulative $\mathrm{CO}_{2}$ was pooled, after $588 \mathrm{~d}$ of incubation, the cumulative amount of SOC respired was statistically greater under warmer incubation temperatures $(p<0.001)$. There was not a significant land use difference in the cumulative amount of $\mathrm{CO}_{2}$ respired across all 12 soils. 
Table 2. Soil characteristics, cumulative respiration after $588 \mathrm{~d}$ of incubation, and $\mathrm{Q}_{10-\mathrm{q}}$ for the six sites and land-use types examined in the cross site comparison. (mean \pm 1 standard deviationt, $n=4$ )

\begin{tabular}{|c|c|c|c|c|c|c|c|c|c|}
\hline \multirow[b]{2}{*}{ Site $\neq$} & \multirow[b]{2}{*}{ Land use§ } & \multirow[b]{2}{*}{ SOC } & \multirow[b]{2}{*}{ Total N } & \multirow[b]{2}{*}{$\mathrm{C} / \mathrm{N}$} & \multicolumn{3}{|c|}{ Cumulative respiration ( $\%$ total soil C) } & \multicolumn{2}{|c|}{$\mathrm{Q}_{10-\mathrm{q}}$ I } \\
\hline & & & & & $15^{\circ} \mathrm{C}$ & $25^{\circ} \mathrm{C}$ & $35^{\circ} \mathrm{C}$ & Labile\# & More resistantt† \\
\hline & & $\mathrm{g} \mathrm{kg}^{-1}$ & $\mathrm{~g} \mathrm{~kg}^{-1}$ & & & & & & \\
\hline SK & NG & 37.1 & 3.58 & 10.4 & $6.52 \pm 0.37$ & $10.40 \pm 0.60$ & $14.37 \pm 0.23$ & $1.6 \pm 0.0$ & $2.5 \pm 0.2$ \\
\hline SK & $\mathrm{C}$ & 22.9 & 2.04 & 11.2 & $4.33 \pm 0.14$ & $7.73 \pm 0.53$ & $13.05 \pm 0.50$ & $2.0 \pm 0.1$ & $3.3 \pm 1.3$ \\
\hline ND & NG & 32.4 & 2.93 & 11.0 & $3.93 \pm 0.30$ & $8.14 \pm 0.68$ & $15.03 \pm 2.90$ & $1.7 \pm 0.1$ & $2.7 \pm 0.2$ \\
\hline ND & $\mathrm{C}$ & 28.0 & 2.40 & 11.7 & $5.17 \pm 0.16$ & $9.17 \pm 0.44$ & $11.32 \pm 1.06$ & $1.5 \pm 0.1$ & $1.3 \pm 0.2$ \\
\hline $\mathrm{CO}$ & NG & 11.6 & 1.35 & 8.6 & $9.64 \pm 0.65$ & $17.93 \pm 0.53$ & $30.20 \pm 2.39$ & $1.5 \pm 0.1$ & $2.8 \pm 0.3$ \\
\hline $\mathrm{CO}$ & $\mathrm{C}$ & 6.9 & 1.00 & 6.9 & $7.45 \pm 0.25$ & $13.09 \pm 1.58$ & $24.04 \pm 2.58$ & $2.2 \pm 0.2$ & $4.6 \pm 1.4$ \\
\hline $\mathrm{TX}$ & NG & 11.2 & 1.29 & 8.7 & $9.60 \pm 0.46$ & $14.96 \pm 1.10$ & $24.36 \pm 0.43$ & $2.0 \pm 0.2$ & $3.4 \pm 0.5$ \\
\hline TX & $\mathrm{C}$ & 10.2 & 1.25 & 8.1 & $8.62 \pm 0.20$ & $15.61 \pm 0.68$ & $23.22 \pm 1.60$ & $1.6 \pm 0.1$ & $3.1 \pm 0.2$ \\
\hline CR & $\mathrm{NF}$ & 200.2 & 16.60 & 12.1 & $2.04 \pm 0.10$ & $4.21 \pm 0.27$ & $9.70 \pm 0.53$ & $1.9 \pm 0.2$ & $4.1 \pm 0.4$ \\
\hline $\mathrm{CR}$ & $\mathrm{P}$ & 141.6 & 10.45 & 13.5 & $1.29 \pm 0.05$ & $2.68 \pm 0.07$ & $5.65 \pm 0.17$ & $2.9 \pm 0.3$ & $6.5 \pm 0.4$ \\
\hline $\mathrm{BR}$ & $\mathrm{NF}$ & 10.6 & 1.09 & 9.7 & $5.72 \pm 0.54$ & $11.81 \pm 0.74$ & $19.50 \pm 2.28$ & $2.2 \pm 0.3$ & $1.4 \pm 0.3$ \\
\hline $\mathrm{BR}$ & $\mathrm{P}$ & 14.1 & 1.33 & 10.6 & $6.76 \pm 0.36$ & $10.65 \pm 0.45$ & $21.60 \pm 0.97$ & $2.4 \pm 0.4$ & $4.2 \pm 0.6$ \\
\hline
\end{tabular}

† Standard deviation reported in table is from laboratory replicate.

\# SK, Saskatchewan; ND, North Dakota; CO, Colorado; TX, Texas; CR, Costa Rica; BR, Brazil.

$\S N G$, native grassland; $N F$, native forest; $C$, cultivated; $P$, pasture.

I $\mathrm{Q}_{10-\mathrm{q}}$ was calculated using respiration from the $35 / 25^{\circ} \mathrm{C}$ cumulative respiration.

\# Labile was considered the first $0.5 \%$ SOC respired in the incubation.

t+More resistant was considered the last $0.5 \%$ SOC respired in the incubation.

\section{Temperature Sensitivity}

$\mathrm{Q}_{10-\mathrm{q}}$ values for the labile fraction varied from 1.5 to 2.9 and $\mathrm{Q}_{10 \text {-q }}$ values for the more resistant fraction varied from 1.3 to 6.5. In all but two instances the labile fraction had a smaller $\mathrm{Q}_{10-\mathrm{q}}$ value than the more resistant fraction (Table 2) with North Dakota cultivated and Brazil native forest being the two exceptions. For the North Dakota cultivated and the Brazil native forest the $Q_{10-\mathrm{q}}$ values for the more resistant fraction were much lower than the values for the more resistant fraction of the other soils. The Costa Rica pasture site had the highest $\mathrm{Q}_{10-\mathrm{q}}$ values overall (Table 2). When sites were treated as replicates and $Q_{10-q}$ values were pooled there was a significant difference in $\mathrm{Q}_{10-\mathrm{q}}$ values for the labile and more resistant fractions $(p=$ 0.0026) with the $Q_{10-q}$ for the labile fraction being $1.95 \pm 0.08$ and the more resistant fraction being $3.33 \pm 0.04$. There was no significant land-use treatment effect $(p=0.127)$ or land use by SOM fraction effect $(p=0.338)$. There was a slight positive trend with MAT and $\mathrm{Q}_{10-\mathrm{q}}$ values for the labile fraction $\left(r^{2}=0.336, p\right.$ $=0.048$ ), but no correlation between MAT and $Q_{10-q}$ values for the more resistant fraction $\left(r^{2}=0.092, p=0.337\right)$ for the sites. There was no trend with the soil $\mathrm{C} / \mathrm{N}$ ratio and the $\mathrm{Q}_{10 \text {-q }}$ values for the labile $\left(r^{2}=0.112, p=0.288\right)$ or more resistant fraction $\left(r^{2}=0.056, p=0.457\right)$.

\section{Curve Fitting}

Respiration rates declined over time for all soils at all three incubation temperatures with the two tropical sites (Costa Rica and Brazil) having a much more rapid decline in respiration rates early in the incubation compared with the other four sites (Fig. 1). Respiration rates leveled off for all soils by the end of the incubation, but differences in the respiration rates among the three incubation temperatures were still apparent at the end of the incubation (Fig. 1).

The two-pool equation fit the respiration data fairly well; an exception to this was the Costa Rica native forest soil at $35^{\circ} \mathrm{C}$ where the two-pool equation overestimated the respiration rate later in the incubation (Fig. 1). We also fit the data to a three-pool first-order equation. In the three-pool model, the resistant pool was fixed at half of the total SOM, causing the slow pool to be approximately half the size of the slow pool in the two-pool model. Although estimates of the active pool size and decomposition rate were not statistically different between the two-pool and three-pool equation, the three-pool equation consistently had a smaller active pool compared with the two-pool equation by an average of 5\%. The three-pool equation consistently had a higher decomposition rate of the active pool compared with the two-pool equation by an average of $6 \%$ (Table 3 ). We used the simpler twopool model in all subsequent analysis, realizing that the resistant pool contributes only slightly to the measured respiration because of its high mean residence time.

The native grassland Colorado soil had the largest active pool, comprising between 9.4 and $14.0 \%$ of total SOC at the different temperatures. The Costa Rica native forest soil had the smallest active pool, comprising between 0.1 and $1.0 \%$ of total SOC (Table 4). When sites were treated as replicates and active pool sizes were pooled, in the native grassland/cultivated sites (Saskatchewan, North Dakota, Colorado, and Texas) the native treatment had a significantly larger active pool than the cultivated treatment $(p=0.003)$. The size of the active pool at $25^{\circ} \mathrm{C}$ was negatively correlated with the $\mathrm{C} / \mathrm{N}$ ratio of the soil $\left(r^{2}=0.34, p\right.$ $=0.045$ for all soils; Fig. 2). The relationship between the active pool and $\mathrm{C} / \mathrm{N}$ was improved when the Colorado cultivated and 

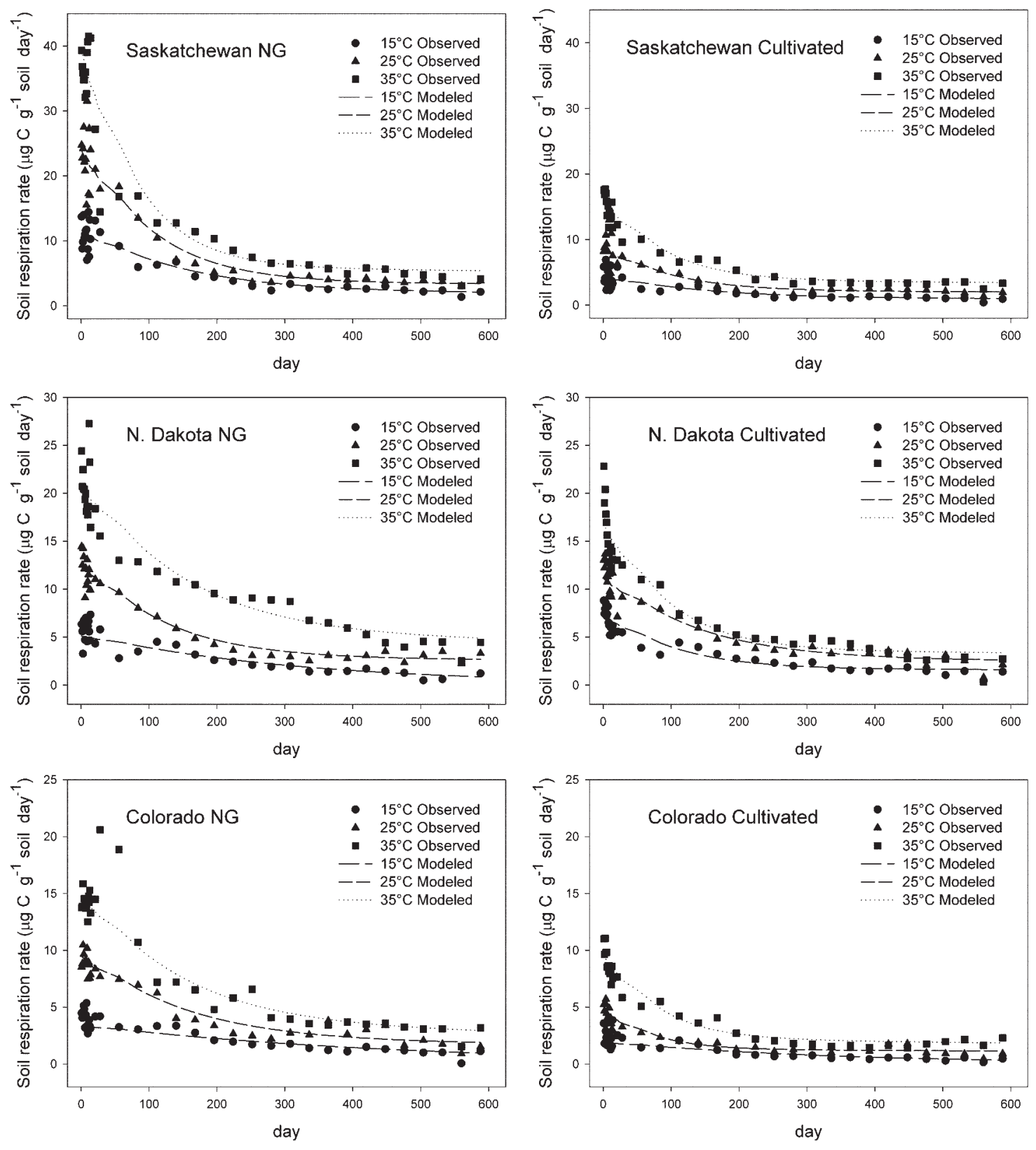

Fig. 1. Decomposition rates over time at 15,25 , and $35^{\circ} \mathrm{C}$ for the twelve soils. NG is native grassland and NF is native forest. Values represent means $(n=4)$. Figure 1 is ontinued on next page.

Brazil native forest soils were removed $\left(r^{2}=0.84, p=0.0002\right)$, which appeared to behave differently than the other soils. There was also a slight correlation with the size of the active pool at $25^{\circ} \mathrm{C}$ and the $\mathrm{Q}_{10-\mathrm{q}}$ value calculated for the labile fraction $\left(r^{2}=\right.$ $0.35, p=0.044)$ with soils having smaller active pools also having higher $\mathrm{Q}_{10-\mathrm{q}}$ values for the labile fraction, but this correlation seemed to be strongly driven by the Costa Rica pasture soil (data not shown).

Some studies have hypothesized that temperature may alter the amount of substrate that would be considered easily decomposable (Zogg et al., 1997; Zak et al., 1999; Dalias et al., 2003; Rasmussen et al., 2006). Because of this, no restrictions were placed on the size of the pools and pool sizes varied with temperature if it provided the best fit of the data. In all but four instances (North Dakota cultivated $35^{\circ} \mathrm{C}$, Texas cultivated $25^{\circ} \mathrm{C}$,
Brazil native forest $25^{\circ} \mathrm{C}$, Costa Rica pasture $25^{\circ} \mathrm{C}$ ) there was an increase in active pool size with temperature. For the four soils where the active pool size declined with increasing temperature, it was likely due to high initial respiration rates that quickly declined over time. The decomposition rates of the slow pool increased with increasing incubation temperature for all of the soils and the decomposition rate for the active pool increased with increasing temperature in only half the instances (Table 4).

\section{Soil Organic Matter Composition}

A large proportion of the mass spectra of each sample could be classified using previously identified marker signals associated with several classes of compounds in the literature (Sorge et al., 1993; Schulten, 1996), leaving only $6.7 \pm 2.5 \%$ of TII unidentified (Table 5). The volatile fraction $(\mathrm{m} / \mathrm{z} 20-56)$ 

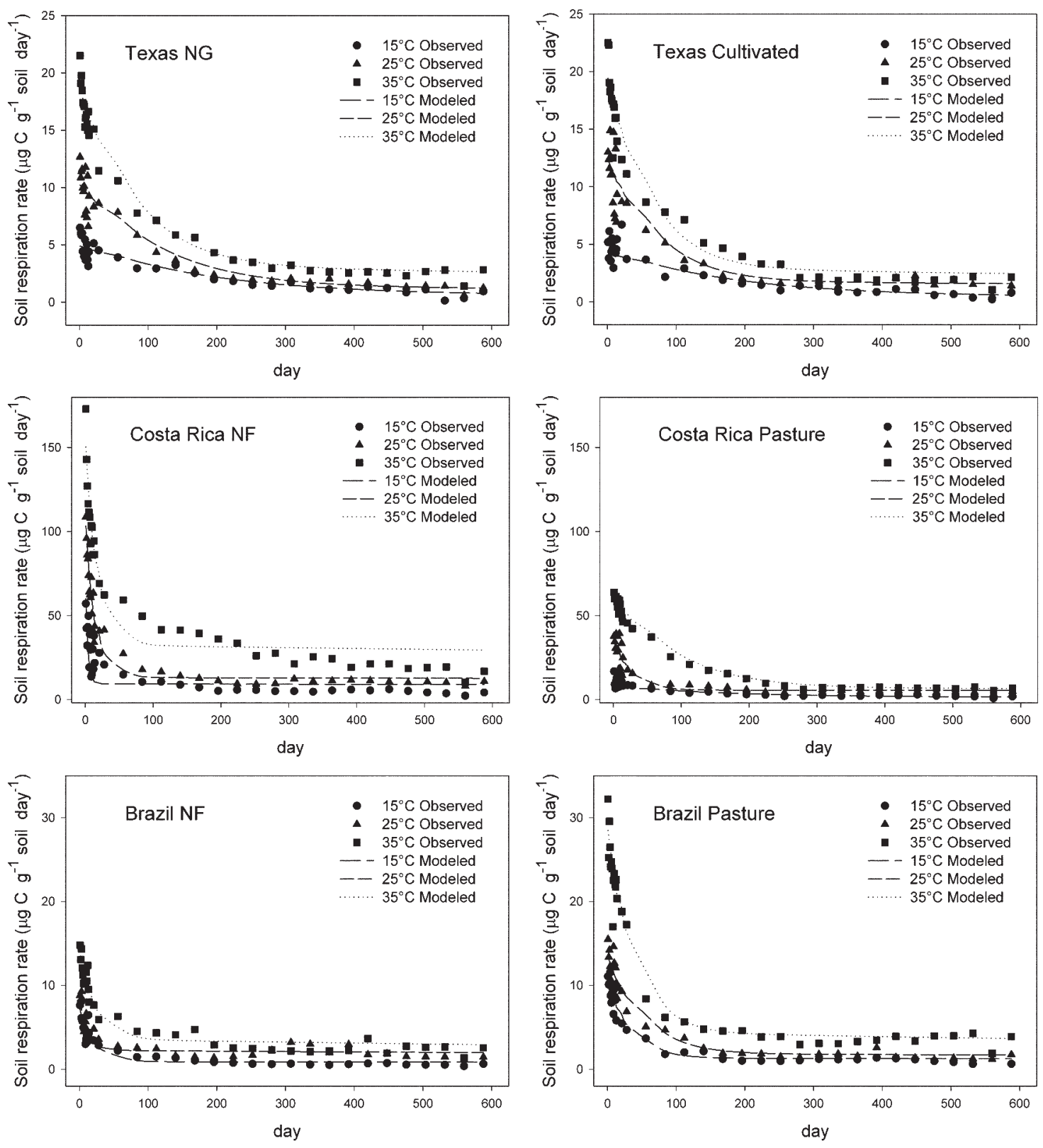

Fig. 1. cont. Decomposition rates over time at 15,25 , and $35^{\circ} \mathrm{C}$ for the twelve soils. NG is native grassland and NF is native forest. Values represent means $(n=4)$.

represented $50.9 \pm 4.5 \%$ of the total signal intensity, dominated by $\mathrm{m} / \mathrm{z} 44\left(\mathrm{CO}_{2}\right)$. The largest classes of identified compounds were various $\mathrm{N}$-containing compounds $(11.9 \pm 1.8 \%$ of TII) and carbohydrates $(10.6 \pm 2.6 \%$ of TII). The various $\mathrm{N}$-containing compounds are identified by Schulten (1996) as heterocyclic $\mathrm{N}$-containing compounds, though it is possible that the heterocyclic $\mathrm{N}$ is formed by the pyrolysis process (Sharma et al.,
2003). Peptides, phenols and lignin monomers, lipids, and alkyl aromatics were also significant contributors (in decreasing order), while sterols and lignin dimers each contributed $<1 \%$ of TII (Table 5). The conversion of native grasslands to agriculture caused a decline in carbohydrates in the temperate soils. There was essentially no change in the proportion of carbohydrates in Costa Rica with conversion from native forest to pasture. There

Table 3. Parameter estimates averaged across all soils and temperatures and fit estimates for the two-pool and three-pool models for the six sites and land use types examined in the cross site comparison.

\begin{tabular}{|c|c|c|c|c|c|c|c|c|}
\hline Model & Active pool & $\begin{array}{l}\text { Active pool decomp. } \\
\text { Rate }\end{array}$ & Slow pool & $\begin{array}{l}\text { Slow pool decomp. } \\
\text { rate }\end{array}$ & Resistant pool & $\begin{array}{l}\text { Resistant pool } \\
\text { decomp. rate }\end{array}$ & RMSE† & $\mathbf{R}_{\mathrm{a}}{ }^{2 \pm}$ \\
\hline & $\mathrm{mg} \mathrm{Cg}^{-1}$ soil & $d^{-1}$ & $\mathrm{mg} \mathrm{Cg}^{-1}$ soil & $d^{-1}$ & mg C g ${ }^{-1}$ soil & $d^{-1}$ & & \\
\hline 2 pool & 1.06 & $2.85 \mathrm{E}-02$ & 42.84 & $1.36 \mathrm{E}-04$ & . & . & 2.07 & 0.83 \\
\hline 3 pool & 1.00 & 3.03E-02 & 20.95 & $3.10 \mathrm{E}-04$ & 21.95 & $1.76 \mathrm{E}-05$ & 2.05 & 0.83 \\
\hline
\end{tabular}

† RMSE, Root Mean Square Error.

$\neq R_{\mathrm{a}}{ }^{2}$, adjusted r-square. 
Table 4. Size of the active pool and active and slow pool decomposition rates at 15,25 , and $35^{\circ} \mathrm{C}$ for the two-pool model for the six sites and land-use types examined in the cross site comparison. Error is model standard error.

\begin{tabular}{|c|c|c|c|c|c|}
\hline Site + & Land use $¥$ & Inc. temp & Active pool & Active pool decomp. rate & Slow pool decomp. rate \\
\hline & & ${ }^{\circ} \mathrm{C}$ & $\%$ total soil C & $d^{-1}$ & $d^{-1}$ \\
\hline \multirow[t]{3}{*}{ SK } & NG & 15 & $3.7 \pm 1.3$ & $6.7 \mathrm{E}-03 \pm 1.97 \mathrm{E}-03$ & $5.6 \mathrm{E}-05 \pm 2.24 \mathrm{E}-05$ \\
\hline & & 25 & $5.3 \pm 1.4$ & $10.3 \mathrm{E}-03 \pm 2.56 \mathrm{E}-03$ & $10.1 \mathrm{E}-05 \pm 3.22 \mathrm{E}-05$ \\
\hline & & 35 & $6.7 \pm 2.1$ & $13.5 \mathrm{E}-03 \pm 4.15 \mathrm{E}-03$ & $17.2 \mathrm{E}-05 \pm 5.83 \mathrm{E}-05$ \\
\hline \multirow{3}{*}{ SK } & $\mathrm{C}$ & 15 & $2.1 \pm 1.5$ & $6.8 \mathrm{E}-03 \pm 4.03 \mathrm{E}-03$ & $4.3 \mathrm{E}-05 \pm 2.52 \mathrm{E}-05$ \\
\hline & & 25 & $2.6 \pm 1.2$ & $10.8 \mathrm{E}-03 \pm 4.73 \mathrm{E}-03$ & $9.6 \mathrm{E}-05 \pm 2.70 \mathrm{E}-05$ \\
\hline & & 35 & $4.2 \pm 0.7$ & $12.6 \mathrm{E}-03 \pm 2.12 \mathrm{E}-03$ & $17.3 \mathrm{E}-05 \pm 1.89 \mathrm{E}-05$ \\
\hline \multirow[t]{3}{*}{ ND } & NG & 15 & ND§ & ND & ND \\
\hline & & 25 & $3.5 \pm 0.7$ & $8.7 \mathrm{E}-03 \pm 1.48 \mathrm{E}-03$ & $8.8 \mathrm{E}-05 \pm 1.33 \mathrm{E}-05$ \\
\hline & & 35 & $7.2 \pm 2.5$ & $6.7 \mathrm{E}-03 \pm 1.89 \mathrm{E}-03$ & $16.7 \mathrm{E}-05 \pm 4.48 \mathrm{E}-05$ \\
\hline \multirow[t]{3}{*}{ ND } & $\mathrm{C}$ & 15 & $2.0 \pm 0.5$ & $10.3 \mathrm{E}-03 \pm 2.35 \mathrm{E}-03$ & $6.0 \mathrm{E}-05 \pm 1.03 \mathrm{E}-05$ \\
\hline & & 25 & $4.0 \pm 1.4$ & $7.6 \mathrm{E}-03 \pm 2.26 \mathrm{E}-03$ & $9.9 \mathrm{E}-05 \pm 2.57 \mathrm{E}-05$ \\
\hline & & 35 & $4.0 \pm 1.1$ & $11.7 \mathrm{E}-03 \pm 2.94 \mathrm{E}-03$ & $13.5 \mathrm{E}-05 \pm 2.76 \mathrm{E}-05$ \\
\hline \multirow[t]{3}{*}{$\mathrm{CO}$} & NG & 15 & ND & ND & ND \\
\hline & & 25 & $9.4 \pm 2.4$ & $6.9 \mathrm{E}-03 \pm 1.42 \mathrm{E}-03$ & $18.5 \mathrm{E}-05 \pm 4.46 \mathrm{E}-05$ \\
\hline & & 35 & $14.0 \pm 2.7$ & $7.1 \mathrm{E}-03 \pm 1.08 \mathrm{E}-03$ & $33.1 \mathrm{E}-05 \pm 5.38 \mathrm{E}-05$ \\
\hline \multirow[t]{3}{*}{$\mathrm{CO}$} & $\mathrm{C}$ & 15 & ND & ND & ND \\
\hline & & 25 & $3.1 \pm 1.0$ & $16.0 \mathrm{E}-03 \pm 5.11 \mathrm{E}-03$ & $19.1 \mathrm{E}-05 \pm 2.94 \mathrm{E}-05$ \\
\hline & & 35 & $7.3 \pm 1.3$ & $14.4 \mathrm{E}-03 \pm 2.48 \mathrm{E}-03$ & $35.2 \mathrm{E}-05 \pm 4.00 \mathrm{E}-05$ \\
\hline \multirow[t]{3}{*}{$\mathrm{TX}$} & NG & 15 & $7.0 \pm 2.7$ & $5.4 \mathrm{E}-03 \pm 1.66 \mathrm{E}-03$ & $5.9 \mathrm{E}-05 \pm 4.35 \mathrm{E}-05$ \\
\hline & & 25 & $8.9 \pm 2.0$ & $9.0 \mathrm{E}-03 \pm 1.80 \mathrm{E}-03$ & $12.5 \mathrm{E}-05 \pm 4.59 \mathrm{E}-05$ \\
\hline & & 35 & $10.0 \pm 1.2$ & $13.8 \mathrm{E}-03 \pm 1.60 \mathrm{E}-03$ & $31.4 \mathrm{E}-05 \pm 3.85 \mathrm{E}-05$ \\
\hline \multirow[t]{3}{*}{$\mathrm{TX}$} & $\mathrm{C}$ & 15 & $6.8 \pm 3.9$ & $5.5 \mathrm{E}-03 \pm 2.51 \mathrm{E}-03$ & $4.7 \mathrm{E}-05 \pm 6.21 \mathrm{E}-05$ \\
\hline & & 25 & $6.7 \pm 2.8$ & $15.7 \mathrm{E}-03 \pm 6.53 \mathrm{E}-03$ & $18.6 \mathrm{E}-05 \pm 8.59 \mathrm{E}-05$ \\
\hline & & 35 & $8.8 \pm 1.4$ & $18.7 \mathrm{E}-03 \pm 2.99 \mathrm{E}-03$ & $31.7 \mathrm{E}-05 \pm 5.19 \mathrm{E}-05$ \\
\hline \multirow[t]{3}{*}{$\mathrm{CR}$} & $\mathrm{NF}$ & 15 & $0.1 \pm 0.0$ & $289 \mathrm{E}-03 \pm 68.7 \mathrm{E}-03$ & $4.6 \mathrm{E}-05 \pm 0.72 \mathrm{E}-05$ \\
\hline & & 25 & $0.6 \pm 0.1$ & $76.4 \mathrm{E}-03 \pm 8.34 \mathrm{E}-03$ & $6.6 \mathrm{E}-05 \pm 0.81 \mathrm{E}-05$ \\
\hline & & 35 & $1.0 \pm 0.1$ & $62.2 \mathrm{E}-03 \pm 8.81 \mathrm{E}-03$ & $16.3 \mathrm{E}-05 \pm 1.41 \mathrm{E}-05$ \\
\hline \multirow[t]{3}{*}{$\mathrm{CR}$} & $\mathrm{P}$ & 15 & $0.7 \pm 0.4$ & $6.2 \mathrm{E}-03 \pm 2.56 \mathrm{E}-03$ & $1.0 \mathrm{E}-05 \pm 0.61 \mathrm{E}-05$ \\
\hline & & 25 & $0.5 \pm 0.1$ & $49.4 \mathrm{E}-03 \pm 11.2 \mathrm{E}-03$ & $4.0 \mathrm{E}-05 \pm 0.78 \mathrm{E}-05$ \\
\hline & & 35 & $3.2 \pm 0.3$ & 11.7E-03 $\pm 0.91 \mathrm{E}-03$ & $4.8 \mathrm{E}-05 \pm 0.62 \mathrm{E}-05$ \\
\hline \multirow[t]{3}{*}{$\mathrm{BR}$} & $\mathrm{NF}$ & 15 & $1.1 \pm 0.2$ & $56.1 \mathrm{E}-03 \pm 11.4 \mathrm{E}-03$ & $8.6 \mathrm{E}-05 \pm 1.90 \mathrm{E}-05$ \\
\hline & & 25 & $0.6 \pm 0.1$ & $111 \mathrm{E}-03 \pm 21.5 \mathrm{E}-03$ & $21.4 \mathrm{E}-05 \pm 2.11 \mathrm{E}-05$ \\
\hline & & 35 & $2.1 \pm 0.3$ & $49.2 \mathrm{E}-03 \pm 9.52 \mathrm{E}-03$ & $34.5 \mathrm{E}-05 \pm 3.46 \mathrm{E}-05$ \\
\hline \multirow[t]{3}{*}{$\mathrm{BR}$} & $\mathrm{P}$ & 15 & $1.9 \pm 0.3$ & $35.9 \mathrm{E}-03 \pm 6.00 \mathrm{E}-03$ & $9.6 \mathrm{E}-05 \pm 1.75 \mathrm{E}-05$ \\
\hline & & 25 & $3.7 \pm 0.7$ & $22.3 \mathrm{E}-03 \pm 4.23 \mathrm{E}-03$ & $13.7 \mathrm{E}-05 \pm 2.55 \mathrm{E}-05$ \\
\hline & & 35 & $6.0 \pm 0.7$ & $29.1 \mathrm{E}-03 \pm 3.76 \mathrm{E}-03$ & $33.5 \mathrm{E}-05 \pm 3.94 \mathrm{E}-05$ \\
\hline
\end{tabular}

† SK, Saskatchewan; ND, North Dakota; CO, Colorado; TX, Texas; CR, Costa Rica; BR, Brazil.

₹ NG, native grassland; $N F$, native forest; $C$, cultivated; $P$, pasture.

$\S N D$ values were not determined because the model calculated negative decomposition rates for the slow pool for these samples

was an increase in carbohydrates with conversion from native forest to pasture in Brazil, consistent with the increase in SOM in the pasture (Table 5). There did not appear to be any correlation with the $\mathrm{Q}_{10 \text {-q }}$ value of the labile or resistant fraction and the percentage of various compounds in each soil (data not shown).

In many of the sites, there were differences in the abundance of chemical compounds identified with py-MBMS between the native and cultivated/pasture treatments. Figure 3 illustrates the differences in chemical composition between the native and cultivated soils for the Saskatchewan site, as an example. The Saskatchewan native grassland had a greater abundance of the lower m/z compounds especially m/z 57 and 96 which are associated with carbohydrates and $\mathrm{m} / \mathrm{z} 67$ and 81 , which are associated with various $\mathrm{N}$ compounds. The cultivated soil had a greater abundance of higher molecular weight compounds, many of which are associated with lipids, lignin, and alkyl aromatics.

Principal components analysis was unable to significantly distinguish SOM composition when all samples were analyzed together (Fig. 4). The first four principal components combined explained $43 \%$ of the variance. Taken together, PCA scores of samples were not tightly grouped on the basis of site or land use, with the exception that native forest and grassland samples appear to be more tightly grouped than cultivated samples. There was minor separation of samples by site along the PC 1 
axis, but SOM composition from those sites was comparatively heterogeneous. Significant clustering was observed on the basis of land-use treatment when sites were analyzed individually (data not shown), although there were no consistent trends across sites. The PCA score results suggest that SOM composition in the allophanic Costa Rica samples was highly homogeneous. Principle component analysis loadings were dominated by low molecular weight and odd-numbered $\mathrm{m} / \mathrm{z}$ fragments, which are likely derived from carbohydrate, amino acid, and peptide sidechains (data not shown).

Sequential application of the Martens' uncertainty test found a small number of $\mathrm{m} / \mathrm{z}$ values that were significantly correlated to respiration rates at Day 5 of the incubation (Table 6). Partial least square regression using this reduced set of independent variables was able to explain $65 \%$ of the variance using the first four components. Respiration rates at Day 5 of the incubation were highly correlated with low molecular components associated primarily with carbohydrates, peptides and various $\mathrm{N}$ compounds. Regression against respiration rates at Day 225 of the incubation resulted in more $\mathrm{m} / \mathrm{z}$ values that were significantly correlated (Table 6), but each correlation coefficient was smaller than those for Day 5. Partial least square regression of the reduced set of independent variables was able to explain $59 \%$ of the variance using the first four components. The additional $\mathrm{m} / \mathrm{z}$ values were generally higher molecular weights. Some were associated with phenols and lignin monomers, lignin dimers, and lipids, but many were not identified by Schulten (1996), Hempfling and Schulten (1990), or Gillespie et al. (2009) as marker signals for specific compounds classes.

\section{DISCUSSION}

During the incubation, the total amount of SOC respired increased with warmer incubation temperatures for all twelve soils. Similar responses across the MAT range of 2 to $25.6^{\circ} \mathrm{C}$ (Table 2) could suggest that increasing global temperatures

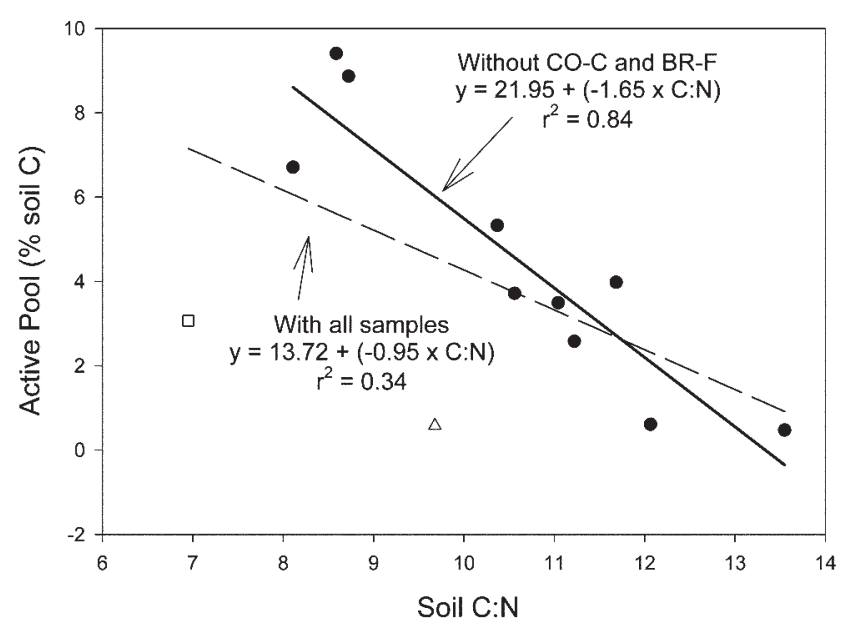

Fig. 2. Correlation between the $\mathrm{C} / \mathrm{N}$ ratio of the soil and the size of the active pool in percentage of total SOC for the 12 soils sampled. All sites are represented by closed circles except Colorado cultivated (CO-C), an unfilled square, and Brazil native forest (BR-NF), an unfilled triangle.

may affect soils equally. The low respiration rates per unit SOC for the allophanic, Costa Rica soils were likely due to the unique mineral composition. Protective effects of amorphous aluminum, iron, and allophanic material have been shown to contribute to the much higher SOM concentrations found in these types of soils (Munevar and Wollum, 1977; Boudot el al., 1986; Martin and Haider, 1986; McKeague et al., 1986). The characteristics that cause SOM accumulation are also likely responsible for the minimal loss of SOC on incubation (Boudot et al., 1988). Respiration rates declined over time in all the soils with the differences in respiration rates between temperatures still apparent at the end of the incubation. Correlations from PLS regression analysis of the py-MBMS products versus the respiration rates could be an indication that higher molecular weight compounds, which tend to be more resistant SOM, were being utilized in the later stages of the incubation. These

Table 5. Proportions (\%) of ion intensity attributable to carbohydrates, peptides, phenols, lignin dimers, lipids, alkyl-aromatics, various $\mathrm{N}$-containing compounds (VCN), sterols and the remaining unknown $\mathrm{m} / \mathrm{z}$ for each of the soils sampled. (mean \pm 1 standard deviation, $n=6$ )

\begin{tabular}{|c|c|c|c|c|c|c|c|c|c|c|c|}
\hline Site & $\begin{array}{l}\text { Land } \\
\text { usef }\end{array}$ & $\begin{array}{c}\mathrm{m} / \mathrm{z} \\
20-56\end{array}$ & Carbs & Peptides & $\begin{array}{l}\text { Phenols \& lignin } \\
\text { monomers }\end{array}$ & $\begin{array}{l}\text { Lignin } \\
\text { dimers }\end{array}$ & Lipids & $\begin{array}{c}\text { Alkyl } \\
\text { aromatics }\end{array}$ & VNC & Sterols & Unknown \\
\hline \multirow[t]{2}{*}{ SK } & NG & 52.8 & 11.0 & 9.7 & 4.0 & 0.3 & 1.8 & 2.5 & 12.9 & 0.3 & 4.7 \\
\hline & $\mathrm{C}$ & 59.0 & 8.0 & 8.2 & 3.0 & 0.6 & 2.5 & 1.9 & 9.6 & 0.6 & 6.6 \\
\hline \multirow[t]{2}{*}{ ND } & NG & 52.8 & 11.0 & 9.1 & 3.9 & 0.3 & 2.0 & 2.2 & 13.1 & 0.3 & 5.1 \\
\hline & $\mathrm{C}$ & 54.4 & 10.1 & 9.4 & 4.0 & 0.3 & 1.8 & 2.1 & 13.1 & 0.3 & 4.5 \\
\hline \multirow[t]{2}{*}{$\mathrm{CO}$} & NG & 51.8 & 9.7 & 8.5 & 3.9 & 0.6 & 3.3 & 2.5 & 11.5 & 0.7 & 7.5 \\
\hline & $\mathrm{C}$ & 48.5 & 8.1 & 8.4 & 4.0 & 1.0 & 5.7 & 2.4 & 9.2 & 1.1 & 11.5 \\
\hline \multirow[t]{2}{*}{ TX } & NG & 53.4 & 9.1 & 8.8 & 3.3 & 0.6 & 3.3 & 2.4 & 11.0 & 0.8 & 7.3 \\
\hline & $\mathrm{C}$ & 52.1 & 8.0 & 7.5 & 3.5 & 0.9 & 4.8 & 2.2 & 9.3 & 1.1 & 10.7 \\
\hline \multirow[t]{2}{*}{$\mathrm{CR}$} & $\mathrm{NF}$ & 41.0 & 15.6 & 12.3 & 6.0 & 0.5 & 2.9 & 2.3 & 14.2 & 0.4 & 4.8 \\
\hline & $\mathrm{P}$ & 47.5 & 15.4 & 11.2 & 4.6 & 0.3 & 1.8 & 2.1 & 13.3 & 0.3 & 3.5 \\
\hline \multirow[t]{2}{*}{$\mathrm{BR}$} & $\mathrm{NF}$ & 50.0 & 9.6 & 9.4 & 4.2 & 0.6 & 3.3 & 2.1 & 12.8 & 0.6 & 7.5 \\
\hline & $\mathrm{P}$ & 47.6 & 11.8 & 10.3 & 4.4 & 0.5 & 2.8 & 2.5 & 13.4 & 0.6 & 6.2 \\
\hline Mean & & $50.9 \pm 4.5$ & $10.6 \pm 2.6$ & $9.4 \pm 1.4$ & $4.1 \pm 0.7$ & $0.5 \pm 0.2$ & $3.0 \pm 1.2$ & $2.3 \pm 0.2$ & $11.9 \pm 1.8$ & $0.6 \pm 0.3$ & $6.7 \pm 2.5$ \\
\hline
\end{tabular}

† SK, Saskatchewan; ND, North Dakota; CO, Colorado; TX, Texas; CR, Costa Rica; BR, Brazil.

₹ NG, native grassland; NF, native forest; $C$, cultivated; $P$, pasture. 

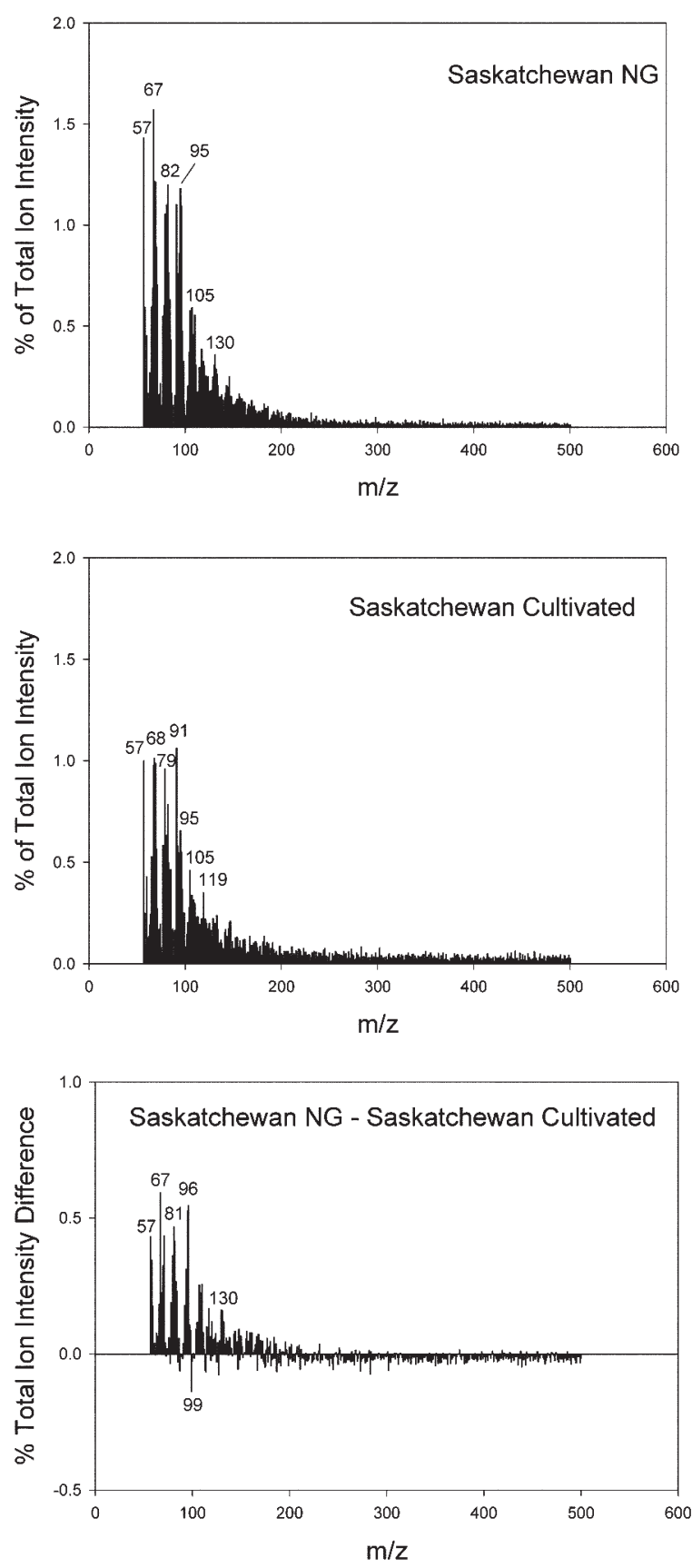

Fig. 3. Normalized mass spectrum for spectral range $m / z=57-500$ from the pyrolysis molecular beam mass spectrometry analysis of Saskatchewan native grassland (NG), Saskatchewan cultivated, and the difference between the two spectra. In the difference graph $\mathrm{m} / \mathrm{z}$ that are more abundant in the native grassland are positive and $\mathrm{m} / \mathrm{z}$ that are more abundant in the cultivated are negative. Spectra are means of six samples.

correlations support the first assumption of the $\mathrm{Q}_{10-\mathrm{q}}$ method, that changes in decomposition rates are driven by changes in easily decomposable substrate.

In most instances the more resistant SOM was more temperature sensitive than the labile SOM. We utilized the same method of determining temperature sensitivity of SOM decomposition as described by Conant et al. (2008a) along with two of the same sites (Colorado and Texas) and observed similar results with an expanded set of sites. Our results and

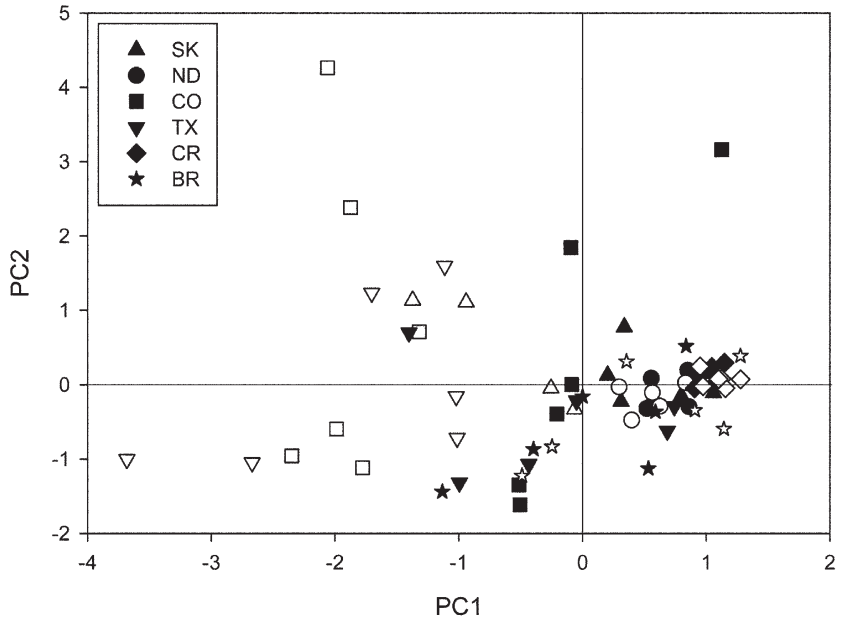

Fig. 4. Principle component analysis scores of whole-soil samples analyzed by py-MBMS for the twelve soils sampled. Closed symbols are native treatments, open symbols are cultivated or pasture treatments.

those of Conant et al. (2008a) are consistent with multiple other studies (Bosatta and Ågren, 1999; Bol et al., 2003; Fierer et al., 2005; Knorr et al., 2005; Conant et al., 2008b). However, it is important to point out that there were two soils in our study that did not follow this overall trend and in those two soils the more resistant fraction had a lower $\mathrm{Q}_{10-\mathrm{q}}$ value than the labile fraction and the $\mathrm{Q}_{10-\mathrm{q}}$ value of the more resistant fraction was also much lower than those determined for the other soils. For the North Dakota cultivated soil, the $\mathrm{Q}_{10 \text {-q }}$ value calculated throughout the course of the incubation varied very little and the Brazil forest soil increased to a value of 4.5 and then declined down to 1.4 (data not shown). Our results illustrate how a study that utilizes a single soil for determining temperature sensitivity of SOM decomposition could possibly come to a different conclusion with regards to SOM temperature sensitivity.

We compared the temperature sensitivity of the first $0.5 \%$ $(\mathrm{w} / \mathrm{w})$ soil $\mathrm{C}$ respired to the last $0.5 \%(\mathrm{w} / \mathrm{w})$ soil $\mathrm{C}$ respired. Since this is an operationally defined fraction it is possible that a longer incubation could affect the results. Respiration rates had leveled off by the end of the incubation and we don't believe extending our incubation further would alter our results significantly because we would not be accessing a different pool of $\mathrm{SOM}$ at this point. Incubations are limited by the fact that the truly resistant $\mathrm{C}$ with mean residence times of millennia is not accessed by the microbes and we are more likely just accessing the rather large intermediate pool of SOM. There is a possibility that our cut off limit of flushing jars before $\mathrm{CO}_{2}$ reached 5\%(v/v) may have caused an inhibition of microbial activity, although there was no indication in the respiration data that this occurred. If there was any inhibition of microbial activity it would have likely occurred early in the incubation at the warmer incubation temperatures, when respiration rates were high. If this did occur it may have caused us to underestimate the $\mathrm{Q}_{10-\mathrm{q}}$ for the labile fraction and the size of the active pool at the warmer incubation temperatures. Although we believe that any underestimation would have been slight and not change the overall trends. 
The estimated size of the active pool for all the sites ranged from 0.1 to $14.0 \%$ of initial SOC (Table 4). This range for the active pool is slightly wider than results found by Rey and Jarvis (2006), which ranged from 0.27 to $11.4 \%$. Many other studies have estimates that fall within these ranges (Collins et al., 2000; Haile-Mariam et al., 2000; Cochran et al., 2007). Our wider range of estimates for the active pool is likely due to the wide range of soils and incubation temperatures utilized. The soils from the two central sites, Texas and Colorado, respired the most total SOC by the end of the incubation and had the largest active pools, contrary to the comparison of forested tropical soils and dry forested temperate soils by Trumbore (1993) in which the tropical soils were comprised of more labile $\mathrm{C}$ in the upper $22 \mathrm{~cm}$ than temperate soils. The larger active pools in our temperate soils and higher cumulative respiration could be due to the greater amount of $\mathrm{N}$ in the soils, which indicates a higher proportion of proteinaceous constituents. Our results are consistent with Thomsen et al. (2008), who found the $\mathrm{C} / \mathrm{N}$ ratio to be an indicator of the decomposability of the SOM in a soil, with soils having lower $\mathrm{C} / \mathrm{N}$ ratios having greater $\mathrm{CO}_{2}$ evolution up to a certain threshold.

Temperature-induced changes in pool sizes could be an indication that warmer temperatures may enable microbes to quickly decompose a larger portion of SOM. Increased active pool size with increased temperature evidenced in this study indicates that at warmer temperatures SOM otherwise unavailable to microbes at lower temperatures becomes available for decomposition. This could be attributed to shifts in microbial community composition at different temperatures (Zogg et al., 1997; Zak et al., 1999), changes in substrate use (Andrews et al., 2000; Schimel and Mikan, 2005), or the overcoming of biochemical resistance of SOM by microbes (Conant et al., 2008a).

We utilized different land use treatments at these sites to compare soils with the same MAT but varying amounts and types of SOM, since soils under long-term cultivation would likely have less easily decomposable SOM than the native counterparts. For the four native grassland/cultivated sites, the native grassland treatments respired a greater amount of total soil $\mathrm{C}$ and had larger active pools then their cultivated counterparts. The native grassland soils had greater percentages of carbohydrates as found by py-MBMS, which could be the reason for the greater respiration and larger active pool. Plante et al. (2009), also utilizing py-MBMS, found that cultivation resulted in significant decreases in carbohydrates, peptides, and phenols. Surprisingly, the decline in carbohydrates with cultivation did not result in significant trends in $Q_{10-q}$ values with land use. Our MAT gradient also did not produce consistent trends with regards to temperature sensitivity. It may have been that differences in soil characteristics among sites were too great to elucidate trends with MAT.

Different stabilization mechanisms may alter the reaction rate of SOM decomposition as much as the temperature sensitivity of the SOM. The Costa Rica site with its very low decomposition because of the interactions with sesquioxides had
40 to $42 \%$ of its pyrolysis products identified as carbohydrates, peptides, and various $\mathrm{N}$ containing materials that are normally considered to be more easily decomposable and contribute to the size of the active pool as measured in this study. The Colorado soils had much less of their pyrolysis products identified as carbohydrates and $\mathrm{N}$ containing materials yet the size of the active pool was 2 to 14 times the size of that of Costa Rica at $35^{\circ} \mathrm{C}$. The otherwise decomposable materials are protected in the Costa Rica soils with the Costa Rica pasture soil having noticeably higher $Q_{10-q}$ values for the labile and more resistant fraction. This suggests that the adsorbed materials have even greater temperature sensitivity than soils that have less SOM stabilization. This could mean that the mineral associated SOC constituents could be more affected by global climate change.

We were unable to link differences between apparent temperature sensitivity of SOM, measured as $Q_{10-q}$, to MAT at the site, land use, the size of the active pool, or the chemical composition of SOM determined by py-MBMS. This lack of a strong correlation between methods that characterize the organic matter and the $\mathrm{Q}_{10 \text {-q }}$ values could indicate that chemical stabilization with silt and clay is a greater determinant of temperature sensitivity than biochemical stabilization through the inherent makeup of the organic matter.

The size of our estimated active pool did increase with warmer incubation temperatures for most soils indicating that there may be changes in microbial community or function with temperature that should be considered in model incorporation. Our results indicate that although individual soils may have varying apparent temperature sensitivities for labile versus more resistant SOM depending on the inherent characteristics of the soil, overall the more resistant SOM tends to be more temperature sensitive. Although not directly studied in our experiment, our results indicate that physicochemical stabilization may be a more important determinant of temperature sensitivity of SOM than biochemical stabilization. Understanding the differences between inherent and apparent temperature sensitivity is an area that still requires more investigation to better model temperature effects on SOM decomposition.

\section{ACKNOWLEDGMENTS}

M. Vigil, R. Teague, D. Tanaka, C.C. Cerri, and C.E.P Cerri assisted with site selection and sampling. Rebecca Greenwood, Jenny Carlson, Matt Carpenter, and Jeremy Schulman assisted in laboratory measurements. This research was supported by the Office of Science (BER), U.S. Department of Energy and a National Science Foundation grant DEB-0444880.

\section{REFERENCES}

Andren, O., and K. Paustian. 1987. Barley straw decomposition in the field-A comparision of models. Ecology 68:1190-1200.

Andrews, J.A., R. Matamala, K.M. Westover, and W.H. Schlesinger. 2000. Temperature effects on the diversity of soil heterotrophs and the delta C-13 of soil-respired CO2. Soil Biol. Biochem. 32:699-706.

Black, A.L., and D.L. Tanaka. 1997. A conservation tillage-cropping systems study in the Northern Great Plains of the United States. p. 335-342. In E. A. Paul (ed.) Soil organic matter in temperate agroecosystems. CRC Press, Inc., Boca Raton, FL. 
Bol, R., T. Bolger, R. Cully, and D. Little. 2003. Recalcitrant soil organic materials mineralize more efficiently at higher temperatures. J. Plant Nutr. Soil Sci 166:300-307.

Bosatta, E., and G.I. Ågren. 1999. Soil organic matter quality interpreted thermodynamically. Soil Biol. Biochem. 31:1889-1891.

Boudot, J.P., B.A. Belhadj, and T. Chone. 1986. Carbon mineralization in andosols and aluminum-rich highland soils. Soil Biol. Biochem. 18:457-461.

Boudot, J.P., A.B.H. Brahim, and T. Chone. 1988. Dependence of carbon and nitrogen mineralization rates upon amorphous metallic constituents and allophanes in highland soils. Geoderma 42:245-260.

Burke, I., J. P. Kaye, S.P. Bird, S.A. Hall, R.L. McCulley, and G.L. Sommerville. 2003. Evaluating and testing models of terrestrial biogeochemistry: The role of temperature in controlling decomposition. p. 225-253. In C. Canham et al. (ed.) Models in ecosystem science. Princeton Univ. Press, Princeton, NJ.

Campbell, C.A., G.P. Lafond, A.P. Moulin, L. Townley-Smith, and R.P. Zentner. 1997. Crop production and soil organic matter in long-term crop rotations in the sub-humid Northern Great Plains of Canada. p. 297-315. In E.A. Paul (ed.) Soil organic matter in temperate agroecosystems. CRC Press, Inc., Boca Raton, FL.

Cerri, C.E.P., K. Paustian, M. Bernoux, R.L. Victoria, J.M. Melillo, and C.C. Cerri. 2004. Modeling changes in soil organic matter in Amazon forest to pasture conversion with the Century model. Glob. Change Biol. 10:815-832.

Cochran, R.L., H.P. Collins, A. Kennedy, and D.F. Bezdicek. 2007. Soil carbon pools and fluxes after land conversion in a semiarid shrub-steppe ecosystem. Biol. Fertil. Soils 43:479-489.

Collins, H.P., E.T. Elliott, K. Paustian, L.C. Bundy, W.A. Dick, D.R. Huggins, A.J.M. Smucker, and E.A. Paul. 2000. Soil carbon pools and fluxes in longterm corn belt agroecosystems. Soil Biol. Biochem. 32:157-168.

Conant, R.T., R.A. Drijber, M.L. Haddix, W.J. Parton, E.A. Paul, A.F. Plante, J. Six, and J.M. Steinweg. 2008a. Sensitivity of organic matter decomposition to warming varies with its quality. Glob. Change Biol. 14:868-877.

Conant, R.T., J.M. Steinweg, M.L. Haddix, E.A. Paul, A.F. Plante, and J. Six. 2008b. Experimental warming shows that decomposition temperature sensitivity increases with soil organic matter recalcitrance. Ecology 89:2384-2391.

Conen, F., J. Leifeld, B. Seth, and C. Alewell. 2006. Warming mineralises young and old soil carbon equally. Biogeosciences 3:515-519.

Dalias, P., G.D. Kokkoris, and A.Y. Troumbis. 2003. Functional shift hypothesis and the relationship between temperature and soil carbon accumulation. Biol. Fertil. Soils 37:90-95.

Davidson, E.A., and I.A. Janssens. 2006. Temperature sensitivity of soil carbon decomposition and feedbacks to climate change. Nature 440:165-173.

Del Grosso, S.J., W.J. Parton, A.R. Mosier, E.A. Holland, E. Pendall, D.S, Schimel, and D.S. Ojima. 2005. Modeling soil $\mathrm{CO}_{2}$ emissions from ecosystems. Biogeochemistry 73:71-91.

Fang, C.M., P. Smith, J.B. Moncrieff, and J.U. Smith. 2005. Similar response of labile and resistant soil organic matter pools to changes in temperature. Nature 433:57-59.

Fierer, N., J.M. Craine, K. McLauchlan, and J.P. Schimel. 2005. Litter quality and the temperature sensitivity of decomposition. Ecology 86:320-326.

Fissore, C., C.P. Giardina, C.W. Swanston, G.M. King, and R.K. Kolka. 2009. Variable temperature sensitivity of soil organic carbon in North American forests. Glob. Change Biol. 15:2295-2310.

Follett, R.F., E.A. Paul, and E.G. Pruessner. 2007. Soil carbon dynamics during a long-term incubation study involving C-13 and C-14 measurements. Soil Sci. 172:189-208.

Friedlingstein, P., P. Cox, R. Betts, L. Bopp, W. Von Bloh, V. Brovkin, P. Cadule, S. Doney, M. Eby, I. Fung, G. Bala, J. John, C. Jones, F. Joos, T. Kato, M. Kawamiya, W. Knorr, K. Lindsay, H.D. Matthews, T. Raddatz, P. Rayner, C. Reick, E. Roeckner, K.G. Schnitzler, R. Schnur, K. Strassmann, A.J. Weaver, C. Yoshikawa, and N. Zeng. 2006. Climate-carbon cycle feedback analysis: Results from the (CMIP)-M-4 model intercomparison. J. Clim. 19:3337-3353.

Gillabel, J., B. Cebrian-Lopez, J. Six, and Roel Merckx. 2010. Experimental evidence for the attenuating effects of SOM protection on temperature sensitivity of SOM decomposition. Glob. Change Biol. 10.1111/j.13652486.2009.02132.x.

Gillespie, A.W., F.L. Walley, R.E. Farrell, P. Leinweber, A. Schlichting, K.U. Eckhardt, T.Z. Regier, and R.I.R. Blyth. 2009. Profiling rhizosphere chemistry: Evidence from carbon and nitrogen K-edge XANES and
pyrolysis-FIMS. Soil Sci. Soc. Am. J. 73:2002-2012.

Giardina, C.P., and M.G. Ryan. 2000. Evidence that decomposition rates of organic carbon in mineral soil do not vary with temperature. Nature 404:858-861.

Haile-Mariam, S., W. Cheng, D.W. Johnson, J.T. Ball, and E.A. Paul. 2000. Use of carbon-13 and carbon- 14 to measure the effects of carbon dioxide and nitrogen fertilization on carbon dynamics in ponderosa pine. Soil Sci. Soc. Am. J. 64:1984-1993.

Halvorson, A.D., M.F. Vigil, G.A. Peterson, and E.T. Elliot. 1997. Long-term tillage and crop residue management study at Akron, Colorado. p. 361370. In E. A. Paul (ed.) Soil organic matter in temperate agroecosystems. CRC Press, Inc., Boca Raton, FL.

Hempfling, R., and H.R. Schulten. 1990. Chemical characterization of the organic-matter in forest soils by curie-point pyrolysis GC MS and pyrolysis field-ionization mass-spectrometry. Org. Geochem. 15:131-145.

Hess, T.F., and S.K. Schmidt. 1995. Improved procedure for obtaining statistically valid parameter estimates from soil respiration data. Soil Biol. Biochem. 27:1-7.

Hoover, C.M., K.A. Magrini, and R.J. Evans. 2002. Soil carbon content and character in an old-growth forest in northwestern Pennsylvania: A case study introducing pyrolysis molecular beam mass spectrometry (pyMBMS). Environ. Pollut. 116:S269-S275.

Kandeler, E. 2007. Physiological and biochemical methods for studying soil biota and their function. p. 53-83. In E.A. Paul (ed.) Soil microbiology, ecology, and biochemistry. 3rd ed. Academic Press, Boston, MA.

Knorr, W., I.C. Prentice, J.I. House, and E.A. Holland. 2005. Long-term sensitivity of soil carbon turnover to warming. Nature 433:298-301.

Linn, D.M., and J.W. Doran. 1984. Effect of water-filled pore-space on carbondioxide and nitrous-oxide production in tilled and nontilled soils. Soil Sci. Soc. Am. J. 48:1267-1272.

Liski, J., H. Ilvesniemi, A. Makela, and C.J. Westman. 1999. CO2 emissions from soil in response to climatic warming are overestimated-The decomposition of old soil organic matter is tolerant of temperature. Ambio 28:171-174.

Lloyd, J., and J.A. Taylor. 1994. On the temperature-dependence of soil respiration. Funct. Ecol. 8:315-323.

Magrini, K.A., R.J. Evans, C.M. Hoover, C.C. Elam, and M.F. Davis. 2002. Use of pyrolysis molecular beam mass spectrometry (py-MBMS) to characterize forest soil carbon: Method and preliminary results. Environ. Pollut. 116:S255-S268.

Martin, J.P., and K. Haider. 1986. Influence of mineral colloids on turn-over rates of soil organic carbon. p. 283-304. In P. M. Huang (ed.) Interactions of soil minerals with natural organics and microbes. SSSA, Madison, WI.

Martin, R.E., G.P. Asner, R.J. Ansley, and A.R. Mosier. 2003. Effects of woody vegetation encroachment on soil nitrogen oxide emissions in a temperate savanna. Ecol. Appl. 13:897-910.

McKeague, J.A., M.V. Cheshire, F. Andreux, and J. Berthelin. 1986. Organomineral complexes in relation to pedogenesis. p. 549-592. In P. M. Huang (ed.) Interactions of soil minerals with natural organics and microbes. SSSA, Madison, WI.

Melillo, J.M., J. Borchers, J. Chaney, H. Fisher, S. Fox, A. Haxeltine, A. Janetos, D.W. Kicklighter, T.G.F. Kittel, A.D. McGuire, R. McKeown, R. Neilson, R. Nemani, D.S. Ojima, T. Painter, Y. Pan, W.J. Parton, L. Pierce, L. Pitelka, C. Prentice, B. Rizzo, N.A. Rosenbloom, S. Running, D.S. Schimel, S. Sitch, T. Smith, and I. Woodward. 1995. Vegetation ecosystem modeling and analysis project-Comparing biogeography and biogeochemistry models in a continental-scale study of terrestrial ecosystem responses to climatechange and $\mathrm{CO}_{2}$ doubling. Global Biogeochem. Cycles 9:407-437.

Mikan, C.J., J.P. Schimel, and A.P. Doyle. 2002. Temperature controls of microbial respiration in arctic tundra soils above and below freezing. Soil Biol. Biochem. 34:1785-1795.

Munevar, F., and A.G. Wollum. 1977. Effects of addition of phosphorus and inorganic nitrogen on carbon and nitrogen mineralization in andepts from Colombia. Soil Sci. Soc. Am. J. 41:540-545.

Paul, E.A., S.J. Morris, and S. Böhm. 2001. The determination of soil C pool sizes and turnover rates: Biophysical fractionation and tracers. p. 193-206. In R. Lalet al. (ed.) Assessment methods for soil carbon. Lewis Publishers, Boca Raton, FL.

Paustian, K., W.J. Parton, and J. Persson. 1992. Modeling soil organic matter in organic-amended and nitrogen-fertilized long-term plots. Soil Sci. Soc. Am. J. 56:476-488. 
Plante, A.F., K. Magrini-Bair, M. Vigil, and E.A. Paul. 2009. Pyrolysis-molecular beam mass spectrometry to characterize soil organic matter composition in chemically isolated fractions from differing land uses. Biogeochemistry 92:145-161.

Rasmussen, C., R.J. Southard, and W.R. Horwath. 2006. Mineral control of organic carbon mineralization in a range of temperate conifer forest soils. Glob. Change Biol. 12:834-847.

Rey, A., and P. Jarvis. 2006. Modelling the effect of temperature on carbon mineralization rates across a network of European forest sites (FORCAST). Glob. Change Biol. 12:1894-1908.

Schimel, J.P., and C. Mikan. 2005. Changing microbial substrate use in Arctic tundra soils through a freeze-thaw cycle. Soil Biol. Biochem. 37:1411-1418.

Schulten, H.R. 1996. Direct pyrolysis-mass spectrometry of soils: A novel too in agriculture, ecology, forestry, and soil science. p. 373-436. In T.W. Boutton and S. Yamasaki (ed.) Mass spectrometry of soils. M. Dekker, New York.

Schulten, H.R., R. Hempfling, and W. Zech. 1988. Discriminating horizons in a modern profile by field-ionization mass-spectrometry and patternrecognition. Geoderma 41:211-222.

Sharma, R.K., W.G. Chan, J.I. Seeman, and M.R. Hajaligol. 2003. Formation of low molecular weight heterocycles and polycyclic aromatic compounds (PACs) in the pyrolysis of alpha-amino acids. J. Anal. Appl. Pyrolysis 66:97-121.

Sorge, C., R. Muller, P. Leinweber, and H.R. Schulten. 1993. Pyrolysis massspectrometry of whole soils, soil particle-size fractions, litter materials and humic substances-Statistical evaluation of sample weight, residue, volatilized matter and total ion intensity. Fresenius J. Anal. Chem. 346:697-703.

Steinweg, J.M., A.F. Plante, R.T. Conant, E.A. Paul, and D.L. Tanaka. 2008. Patterns of substrate utilization during long-term incubations at different temperatures. Soil Biol. Biochem. 40:2722-2728.

Thomsen, I.K., B.M. Petersen, S. Bruun, L.S. Jensen, and B.T. Christensen. 2008 Estimating soil $\mathrm{C}$ loss potentials from the $\mathrm{C}$ to $\mathrm{N}$ ratio. Soil Biol. Biochem. 40:849-852.

Trumbore, S.E. 1993. Comparison of carbon dynamics in tropical and temperate soils using radiocarbon measurements. Global Biogeochem. Cycles 7:275-290.

Trumbore, S.E., O.A. Chadwick, and R. Amundson. 1996. Rapid exchange between soil carbon and atmospheric carbon dioxide driven by temperature change. Science 272:393-396.

Vanhala, P., K. Karhu, M. Tuomi, E. Sonninen, H. Jungner, H. Fritze, and J. Liski. 2007. Old soil carbon is more temperature sensitive than the young in an agricultural field. Soil Biol. Biochem. 39:2967-2970.

Zak, D.R., W.E. Holmes, N.W. MacDonald, and K.S. Pregitzer. 1999. Soil temperature, matric potential, and the kinetics of microbial respiration and nitrogen mineralization. Soil Sci. Soc. Am. J. 63:575-584.

Zogg, G.P., D.R. Zak, D.B. Ringelberg, N.W. MacDonald, K.S. Pregitzer, and D.C. White. 1997. Compositional and functional shifts in microbial communities due to soil warming. Soil Sci. Soc. Am. J. 61:475-481. 